\title{
Survival outcomes of CD34+CD38-LSCs and their expression of CD123 in adult AML patients
}

\author{
Asmaa M. Zahran¹, Sanaa Shaker Aly², Amal Rayan³, Omnia El-Badawy4, Maged \\ Abdel Fattah ${ }^{5}$, Arwa Mohammed Ali ${ }^{5}$, Hala M. ElBadre ${ }^{6}$ and Helal F. Hetta ${ }^{4}$ \\ ${ }^{1}$ Clinical Pathology Department, South Egypt Cancer Institute, Assiut University, Assiut, Egypt \\ ${ }^{2}$ Clinical and Chemical Pathology Department, Faculty of Medicine, South Valley University, Qena, Egypt \\ ${ }^{3}$ Clinical Oncology Department, Faculty of Medicine, Assiut University, Assiut, Egypt \\ ${ }^{4}$ Medical Microbiology and Immunology Department, Faculty of Medicine, Assiut University, Assiut, Egypt \\ ${ }^{5}$ Medical Oncology Department, South Egypt Cancer Institute, Assiut University, Assiut, Egypt \\ ${ }^{6}$ Medical Biochemistry Department, Faculty of Medicine, Assiut University, Assiut, Egypt \\ Correspondence to: Amal Rayan, email: amal3774rayan@gmail.com \\ Keywords: acute myeloid leukemia; CD34+CD38-LSCs; CD34+CD38-CD 123+LSCs; disease free survival; overall survival \\ Received: April 23, $2018 \quad$ Accepted: July 31, $2018 \quad$ Published: September 25, 2018 \\ Copyright: Zahran et al. This is an open-access article distributed under the terms of the Creative Commons Attribution License \\ 3.0 (CC BY 3.0), which permits unrestricted use, distribution, and reproduction in any medium, provided the original author and \\ source are credited.
}

\section{ABSTRACT}

Background and aim: Acute myeloid leukemia (AML) is one of the most common leukemias in adults. AML is generally regarded as a stem cell disease characterized by an accumulation of undifferentiated and functionally heterogeneous populations of cells, The aim of the present study was to identify leukemia stem cells in patients with AML and their correlations with treatment outcomes namely remission status, disease free survival, and overall survival.

Results: The mean percentages of $C D 34^{+} C D 38^{-}$and $C D 34^{+} C D 38^{\text {low/- }}$ CD $123^{+}$ LSCs were $2.2 \pm 0.4$ and $22.3 \pm 2.6$, respectively. The percentages of $\mathrm{CD} 34^{+}$cells, CD34 ${ }^{+}$CD $38^{-}$and $C D 34^{+}$CD $38^{\text {low } /-}$ CD123 ${ }^{+}$LSCs were significantly lower in AML patients with complete remission than those without complete response $(P<0.001, P<0.004$, $P<0.001$ respectively). The mean OS of all study patients was $20.03 \pm 1.2$ months while the median OS was 21 months (95\% CI=18.32-21.48). The mean DFS was $16.96 \pm 1.02$ months and the median was 18 months $(95 \% \mathrm{CI}=8.9-11.4)$. DFS and OS were significantly higher among those who achieved CR than those without CR. In addition, there were significant negative effects of WBCs, CD34+cells, CD34+CD38- and CD34+CD38-CD123+LSCs on DFS and OS.

Patients and methods: We investigated 30 patients with newly diagnosed AML; all patients underwent complete history taking, and thorough physical and clinical examination, complete blood count. Peripheral smears and bone marrow aspirates were also examined. Cytochemistry and immunophenotyping of leukemic cells were performed routinely in bone marrow using monoclonal antibodies. Flow cytometry was used to analyze leukemia stem cells and their expression of CD123.

Conclusion: Our study elucidated that CD34+CD38-LSCs, with or without CD123+LSCs phenotype was present in a significant proportion of AML patients and it could be responsible for resistance to traditional treatments, and high percentage of MRD that was translated into significantly high number of non CR, poor DFS, and OS. 


\section{INTRODUCTION}

Acute myeloid leukemia (AML) is one of the most common leukemias in adults. AML is generally regarded as a stem cell disease characterized by an accumulation of undifferentiated and functionally heterogeneous populations of cells $[1,2]$. AML stem cells are CD34 positive cells; in addition they have been recognized as CD38 negative [3]. These CD34+CD38-cells have chemotherapy-resistant properties [4] and are therefore possibly responsible for the outgrowth of minimal residual disease (MRD), which may cause relapse. Treatment failure in AML may be caused by the presence of LSCs [5]. LSCs exist in a stem cell microenvironment, also known as a stem cell niche, in a quiescent state, which allows the LSCs to become chemo resistant [6-7].

To recognize and identify LSCs and their behavior that may play an important role in the approach of targeted therapy. LSCs are considered as CD34+CD38- population and often express CD123, CD44, or CD184, which are rarely expressed on normal hematopoietic stem cells and could be also potential therapeutic targets [8-12]. CD123, the interleukin-3 (IL-3) receptor-alpha subunit, is highly expressed on LSCs [13]. Permanent cure of acute AML by chemotherapy alone remains elusive for most patients because of the inability to eradicate effectively LSCs. By identification of LSC specific cell surface markers, we can distinguish them from normal hematopoietic stem cells, so that, helps effectively to develop therapies targeting them [14]. A better understanding of LSCs and their molecular biology will allow the design of more effective therapies [15]. Although advances in the treatment of AML have led to survival improvement for younger patients, but this is not true for elderly patients where about $70 \%$ of patients 65 years or older die of AML within one year.

The aim of the present study was to identify LSCs in patients with AML and their correlations with treatment outcomes namely remission status, disease free survival (DFS), and overall survival (OS).

\section{RESULTS}

The present study was carried out on 30 patients with denovo AML, 16 males and 14 females. Their ages ranged from 21 to 67 years with median age 46 years. Demographic, clinical and laboratory data of patients with AML were demonstrated in (Table 1,2).

The mean percentage of blast cells in BM of AML patients was $62.08 \pm 4.14$ with a range of $(24-95 \%)$ and in peripheral blood was $31.42 \pm 1.24$ with a range of (11.353.3). The mean percentage of CD34 expression in the blast cells was $49.48 \pm 4.06$ with range $(2-92 \%)$, while the mean percentage of $\mathrm{CD} 34^{+} \mathrm{CD} 38^{-}$leukemic stem cells was $2.23 \pm 0.38$ with a range of $(0.7-9.3 \%)$, and the mean percentage of $\mathrm{CD} 34^{+} \mathrm{CD} 38^{\text {low } /-} \mathrm{CD} 123^{+}$cells was $22.25 \pm$ 2.59 with a range of (1-46.2\%) as shown in (Table 2).
Twenty one of AML patients (70\%) achieved complete remission (CR) after induction chemotherapy. while nine patients $(30 \%)$ did not achieve complete remission (non $-\mathrm{CR}$ ). When the demographic and hematological parameters among $\mathrm{CR}$ and non- CR groups were compared (Table 3). There was no statistical significant difference regarding age, hemoglobin and platelets count between CR and non CR groups. While white blood cell count and BM blasts were significantly decreased in CR group than non-CR group $(P<0.001$ and $P<0.005$ respectively). In addition to that, the percentage of CD34+ leukemic cells, CD34+CD38- leukemic cells and $\mathrm{CD} 34^{+} \mathrm{CD} 38^{\text {low } /} \mathrm{CD} 123^{+}$cells were also significantly reduced in AML patients with CR than those with non-CR $(P<0.001, P<0.004, P<0.001$ respectively).

\section{Survival analysis among the study group}

The mean OS of the whole study patients was $20.03 \pm 1.22$ months while the median OS was 21 months (95\% CI $=18.32-21.48$ ) (Figure 1), moreover, the mean DFS was $16.96 \pm 1.02$ months and the median was 18 months (95\% CI=8.8-11.6) (Figure 2).

As shown in (Table 4) and (Figures 3, 4), the mean OS of AML patients with complete remission was significantly higher than those who failed to achieve complete remission $(23.5 \pm 1.01$ vs. $10 \pm 0.7, P<0.000)$ and the median was (24 vs. 12 months, respectively). Similarly, the mean DFS of AML patients with complete remission was significantly higher than those who failed to achieve complete remission $(10.1 \pm 0.6$ vs. $19.9 \pm 0.9, \mathrm{P}<0.000)$ and the median was ( 20 vs. 10 months, respectively).

There were significant negative correlations between WBCs, CD $34^{+} \mathrm{LSCs}, \mathrm{CD} 34^{+} \mathrm{CD} 38^{\text {low } /} \mathrm{LSCs}$, $\mathrm{CD} 34^{+} \mathrm{CD} 38^{\text {low } /-} \mathrm{CD} 123^{+} \mathrm{LSCs}$ and DFS, also significant negative correlations between the same factors and OS implicating difficulty of salvage therapy or reinduction therapy to prolong survival in this group of AML patients, correlations couldn't be done between FAB type and survival (because of small number of patients in each type and different types of variables as FAB is categorical variable while survival is numeric one), as shown in (Table 5).

\section{DISCUSSION}

LSCs are known by their ability to undergo selfrenewal and their capacity to differentiate $[16,17]$. For clinical treatment and patient survival it is important to know which putative LSCs will survive therapy. In that respect it is important to realize that the $\mathrm{CD} 34^{+} \mathrm{CD} 38^{-}$ compartment has been shown to be the most therapy resistant in vitro [18].

In this study, we found that the mean proportion of $\mathrm{CD} 34^{+} \mathrm{CD} 38^{\text {low } /}-$ LSCs was statistically significantly lower in patient with acute leukemia in CR compared to patients 
Table 1: Demographic data of AML patients

\begin{tabular}{lc}
\hline Item & Patients (30) \\
\hline Age & $46 \pm 2.10$ \\
Sex & $16 / 14$ \\
(male/female) & $53.33 \% / 46.67 \%$ \\
WBCs $\left(10^{9} / \mathrm{L}\right)$ & $31.15 \pm 4.46$ \\
Platelets $\left(10^{9} / \mathrm{L}\right)$ & $36.57 \pm 3.54$ \\
Hemoglobin $(\mathrm{gm} / \mathrm{dl})$ & $7.46 \pm 0.35$ \\
Bone marrow blast $(\%)$ & $62.08 \pm 4.14$ \\
Peripheral blood blast $(\%)$ & $31.42 \pm 1.24$ \\
\hline
\end{tabular}

Data represented as mean \pm SE, mean percentage (blasts) \pm SE, WBCs: white blood cells.

Table 2: Clinical and laboratory characteristics of 30 AML patients

\begin{tabular}{lc}
\hline Characteristic & Descriptive \\
\hline CD34 ${ }^{+}$LSCs & $49.48 \pm 4.06$ \\
CD34 ${ }^{+}$CD38 $8^{\text {low/ }} \mathrm{CD} 123+$ LSCs & $22.25 \pm 2.59$ \\
CD34 $4^{+}$CD $8^{\text {low/ }}$ LSCs & $2.23 \pm 0.38$ \\
FAB classification & \\
M0 & $0(0 \%)$ \\
M1 & $1(3.3 \%)$ \\
M2 & $14(46.7 \%)$ \\
M3 & $8(26.7 \%)$ \\
M4 & $4(13.3 \%)$ \\
M5 & $3(10 \%)$ \\
Response & \\
Remission & $21(70 \%)$ \\
Not in remission & $9(30 \%)$ \\
\hline
\end{tabular}

Abbreviations:AML: Acute myeloid leukemia.

Data expressed as mean percentage \pm SE, numbers, and percentages.

with non-CR and this agreed with Hwang and colleague, who had demonstrated in a group of 54 AML patients, that the proportion of $\mathrm{CD} 34^{+} \mathrm{CD} 38^{\text {low/ }}$ cells at diagnosis was significantly lower in patients achieving CR compared to patients who did not achieve CR [19]. Also our results were in agreement with the results of Wilson et al. and le Viseur et al. [20-21] who reported that there was a correlation between CD38 expression and MRD status, so that AML patients with leukemic blasts expressing CD38 were more likely to be MRD positive.

In our study, we found that the percentage of CD34 $\mathrm{CD} 38^{\text {low } /} \mathrm{CD} 123+$ cells $\left(\mathrm{CD} 123^{+} \mathrm{LSCs}\right)$ was significantly lower in patient with AML with CR than in patients with non-CR and this result came in harmony with the study of Hwang et al., [19] who observed a somewhat higher level of CD123 expression on LSCs in the non-CR group and relapsed group. Also this agreed with Jin et al., who observed that the increased levels of CD123 ${ }^{+}$LSCs in AML patients were known to be associated with a high proportion of blasts and a low CR rate [22].

The burden of LSCs in AML patients is considered a strong biomarker for clinical outcomes in AML [23-24]. $\mathrm{CD}^{2} 4^{+} \mathrm{CD} 38^{-} \mathrm{LSCs}$ frequency is associated with worse outcomes namely remission and survival [5]; AML patients with greater than $3.5 \%$ of $\mathrm{CD} 34^{+} \mathrm{CD} 38^{-}$LSCs show a median relapse free survival of 5.6 mo vs. 16 mo in those with a lower percentage of $\mathrm{CD} 34^{+} \mathrm{CD} 38^{-}$cells [5]. Our results were in agreement with the previous 
Table 3: Relations between response and other variables

\begin{tabular}{|c|c|c|c|}
\hline Variable & Not in remission (9) & Remission (21) & P value $(<0.05)$ \\
\hline \multicolumn{4}{|l|}{ FAB } \\
\hline M1 & 0.0 & $1(4.8 \%)$ & \multirow{5}{*}{$\mathrm{P}=0.357 \mathrm{n} . \mathrm{s}$} \\
\hline M2 & $5(55.0 \%)$ & $9(42.9 \%)$ & \\
\hline M3 & $2(22.2 \%)$ & $6(28.6 \%)$ & \\
\hline M4 & 0.0 & $4(19.0 \%)$ & \\
\hline M5 & $2(22.2 \%)$ & $1(4.8 \%)$ & \\
\hline Blast & $78.93 \pm 2.26$ & $54.85 \pm 20.01$ & $\mathrm{P}<0.005^{* *}$ \\
\hline WBCs & $51.72 \pm 21.19$ & $22.33 \pm 20.37$ & $\mathbf{P}<0.001^{* * *}$ \\
\hline $\mathrm{CD}_{3} 4^{+}$ & $69.22 \pm 28.16$ & $41.01 \pm 12.23$ & $\mathbf{P}<0.001^{* * *}$ \\
\hline $\mathrm{CD} 34^{+} \mathrm{CD} 38^{\text {low } /}-\mathrm{LSCs}$ & $4.85 \pm 1.44$ & $2.53 \pm 1.95$ & $\mathrm{P}<0.004^{* *}$ \\
\hline $\begin{array}{l}\mathrm{CD} 34^{+} \\
\mathrm{CD} 38^{\text {low } /} \mathrm{CD} 123^{+} \text {LSCs }\end{array}$ & $34.73 \pm 7.18$ & $16.90 \pm 13.13$ & $\mathbf{P}<\mathbf{0 . 0 0 1}^{* * * *}$ \\
\hline HB & $7.50 \pm 2.25$ & $7.45 \pm 1.87$ & $\mathrm{P}=0.943 \mathrm{n} . \mathrm{s}$ \\
\hline PLTs & $38.90 \pm 22.14$ & $35.57 \pm 18.60$ & $\mathrm{P}=0.674 \mathrm{n} . \mathrm{s}$ \\
\hline
\end{tabular}

Abbreviations: n.s: non-significant, P-value significant<0.05; PLTs: platelets; HB: hemoglobin, WBCs: white blood cells. $\mathrm{Chi}^{2}$ test, Unpaired $t$-test and Mann Whitney test were used for significance, ${ }^{* *}$ indicates moderately significant, ${ }^{* * *}$ indicates highly significant.

\section{Survival Function}

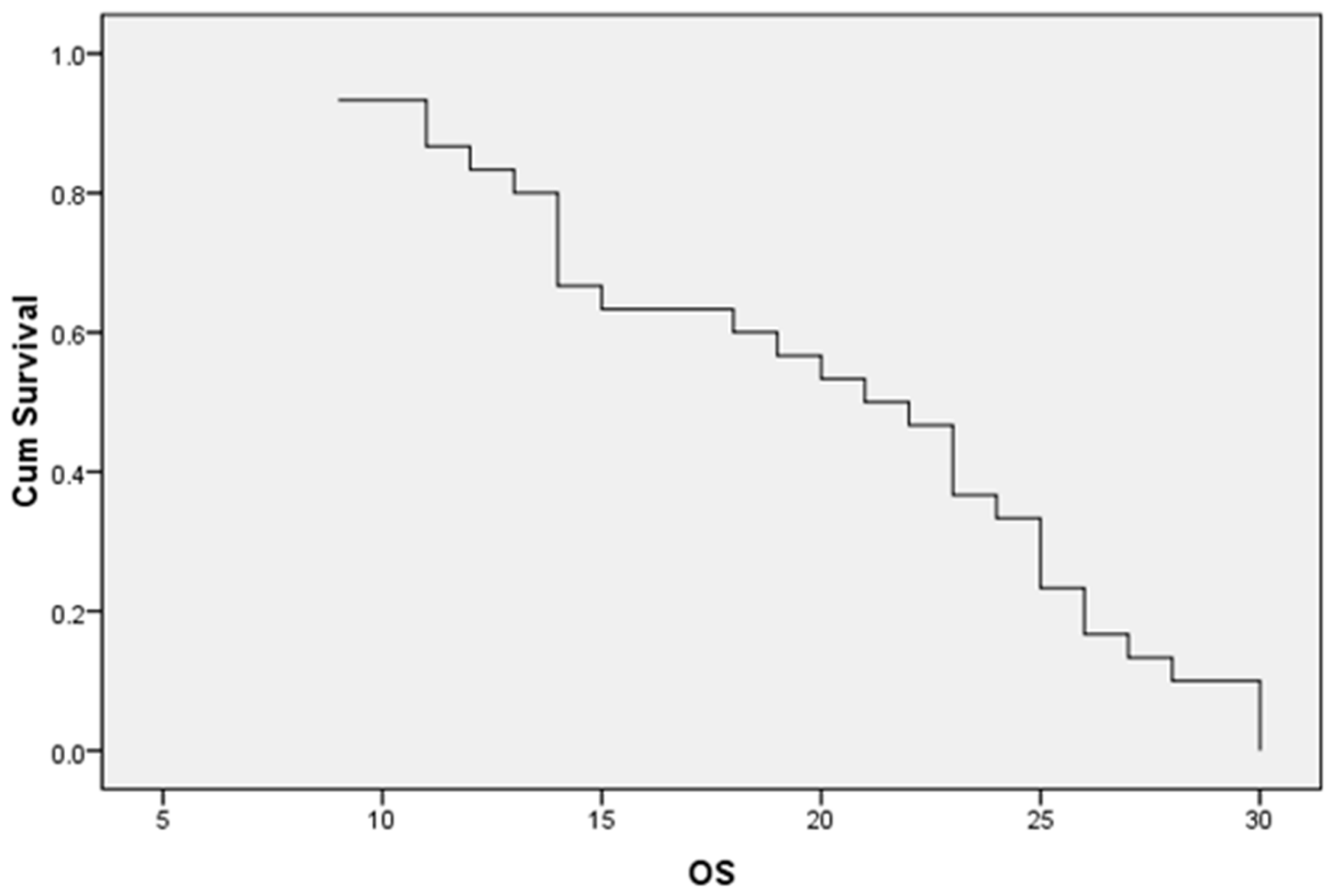

Figure 1: The median OS of the whole AML patients was $21 \mathrm{~ms}(95 \% \mathrm{CI}=18.32-21.48)$. 
Table 4: Relations between treatment response and survival time

\begin{tabular}{|c|c|c|c|}
\hline Item & $\begin{array}{c}\text { Not in remission } \\
" n=9 "\end{array}$ & $\begin{array}{c}\text { Remission } \\
\text { "'n=21" }\end{array}$ & $\begin{array}{l}\text { p-value } \\
<0.05\end{array}$ \\
\hline \multicolumn{4}{|l|}{ 1- DFS } \\
\hline$"$ mean \pm SE" & $10.11 \pm 0.633$ & $19.90 \pm 0.81$ & $\mathbf{P}<\mathbf{0 . 0 0 0}$ *** \\
\hline Median & $10.0 \mathrm{~ms}$ & $20.0 \mathrm{~ms}$ & \\
\hline \multicolumn{4}{|l|}{ 2- OS } \\
\hline "mean \pm SE" & $10.00 \pm 0.70$ & $23.48 \pm 1.01$ & $\mathrm{P}<0.000^{* * *}$ \\
\hline Median & $12.0 \mathrm{~ms}$ & $24.0 \mathrm{~ms}$ & \\
\hline
\end{tabular}

Abbreviations: DFS: disease free survival; OS: overall survival; n: number; SE: standard error, P-value $<0.05$.

${ }^{* * *}$ indicates highly significant.

studies as the high frequency of CD $34^{+} \mathrm{CD} 38^{\text {low/- }} \mathrm{LSCs}$ was translated into no remission and poor DFS and OS.

Several studies confirmed that $\mathrm{CD}^{+} 4^{+} \mathrm{CD} 38^{-}$cell population had a prognostic impact on survival. The median event-free survival (EFS) was 8.2 months (3-year EFS: $29 \%$ ) for those with a higher percentage of CD34+ CD38 versus 91.9 months (3-year EFS: 62\%) for those with a lower percentage [25], our results were comparable with these studies where DFS was significantly impaired by the large number of CD34 ${ }^{+} \mathrm{CD} 38^{\text {low/ }}-\mathrm{LSCs}$ in our patients.

Our results proved that higher number of WBCs was significantly associated with shorter EFS and OS and this

\section{Survival Function}

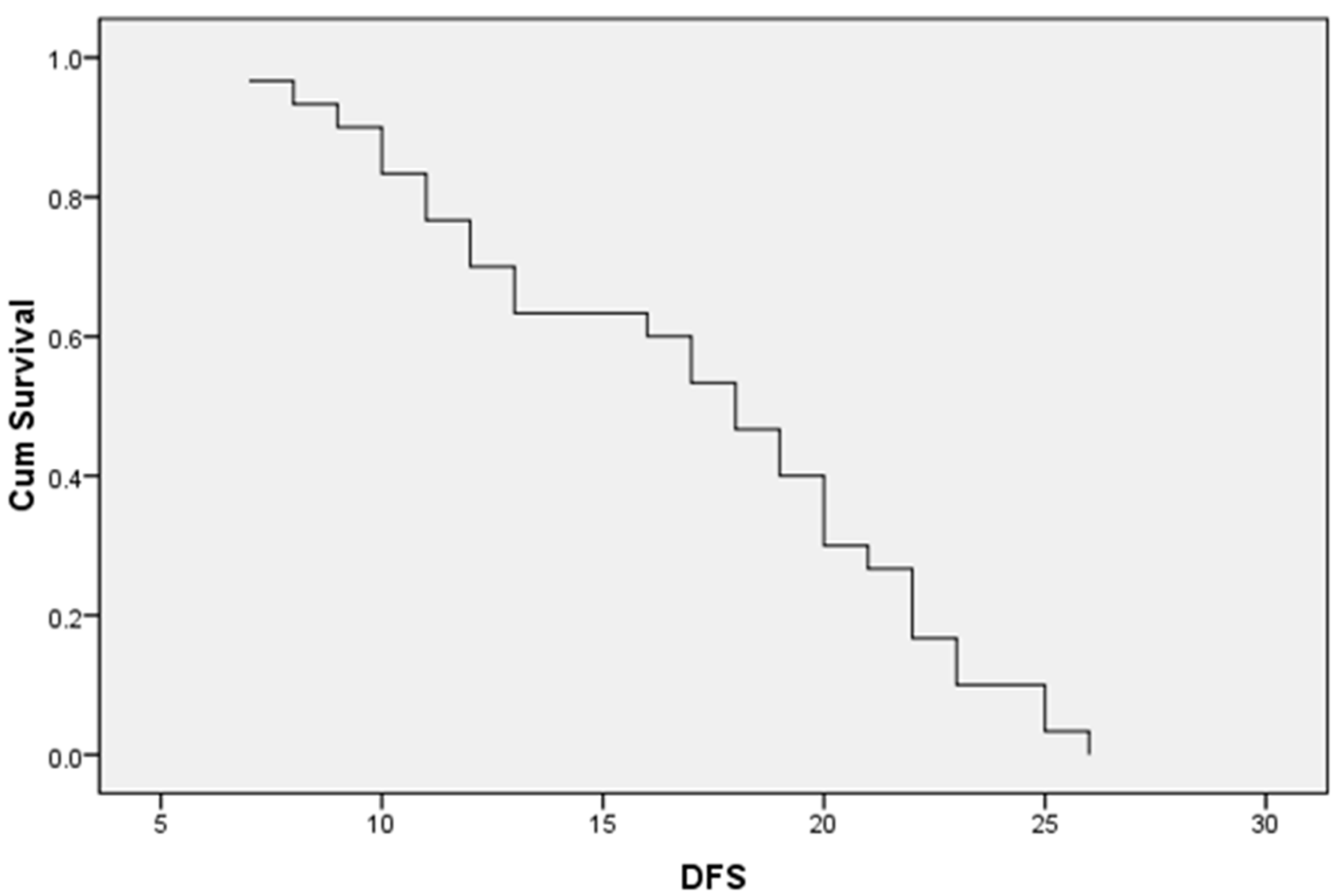

Figure 2: The median DFS of 30 AML patients with a median of $18 \mathrm{~ms}(95 \% \mathrm{CI}=8.87-11.35)$. 
Table 5: Correlations between survival time and different prognostic factors among 30 AML patients

\begin{tabular}{|c|c|c|c|c|}
\hline \multirow[t]{2}{*}{ Prognostic factor } & \multicolumn{2}{|c|}{ DFS $(\mathbf{N}=30)$} & \multicolumn{2}{|c|}{$\mathrm{OS}(\mathrm{N}=30)$} \\
\hline & $\mathbf{r}$ & Pvalue & $\mathbf{r}$ & P value \\
\hline HB level & 0.169 & $0.371 \mathrm{n} . \mathrm{s}$ & 0.200 & $0.289 \mathrm{n} . \mathrm{s}$ \\
\hline WBCs count & -0.728 & 0.000 h.s & -0.586 & $0.001^{* * *}$ \\
\hline Platelets count & 0.030 & $0.873 \mathrm{n} . \mathrm{s}$ & -0.067 & $0.725 \mathrm{n} . \mathrm{s}$ \\
\hline Blasts count & -0.281 & 0.133 n.s & -0.297 & $0.111 \mathrm{n} . \mathrm{s}$ \\
\hline CD34 ${ }^{+} \mathrm{LSCs}$ & -0.562 & $0.001 \mathrm{~m} . \mathrm{s}$ & -0.541 & $0.002^{* *}$ \\
\hline $\mathrm{CD} 34^{+} \mathrm{CD} 38^{\text {low } /-} \mathrm{LSCs}$ & -0.363 & $0.049 \mathrm{~s}$ & -0.398 & $0.029^{*}$ \\
\hline $\mathrm{CD} 34^{+} \mathrm{CD} 38^{\text {low } /-} \mathrm{CD} 123^{+} \mathrm{LSCs}$ & -0.489 & $0.006 \mathrm{~m} . \mathrm{s}$ & -0.489 & $0.005^{* *}$ \\
\hline
\end{tabular}

Pearson correlation was used, and $T$-test for significance with $\mathrm{P}$ value considered significant at $<0.05$, n.s; nonsignificant, *indicates significant, ${ }^{* *}$ indicates moderately significant, ${ }^{* * *}$ indicates highly significant.

came in agreement with other studies [26]. This significant negative correlation between higher WBC counts and reduced OS and DFS could be explained partly by the fact that high WBC counts were associated with an increased risk of tumor lysis syndrome and leukostasis and both were considered oncologic emergencies and subsequently affected the prognosis of patients [27].

The presence of $\mathrm{CD} 123$ on $\mathrm{AML} \mathrm{CD} 34^{+} / \mathrm{CD} 38^{-}$ cells has a potential significance. It is demonstrated that LSCs are biologically distinct from their normal stem

\section{Survival Functions}

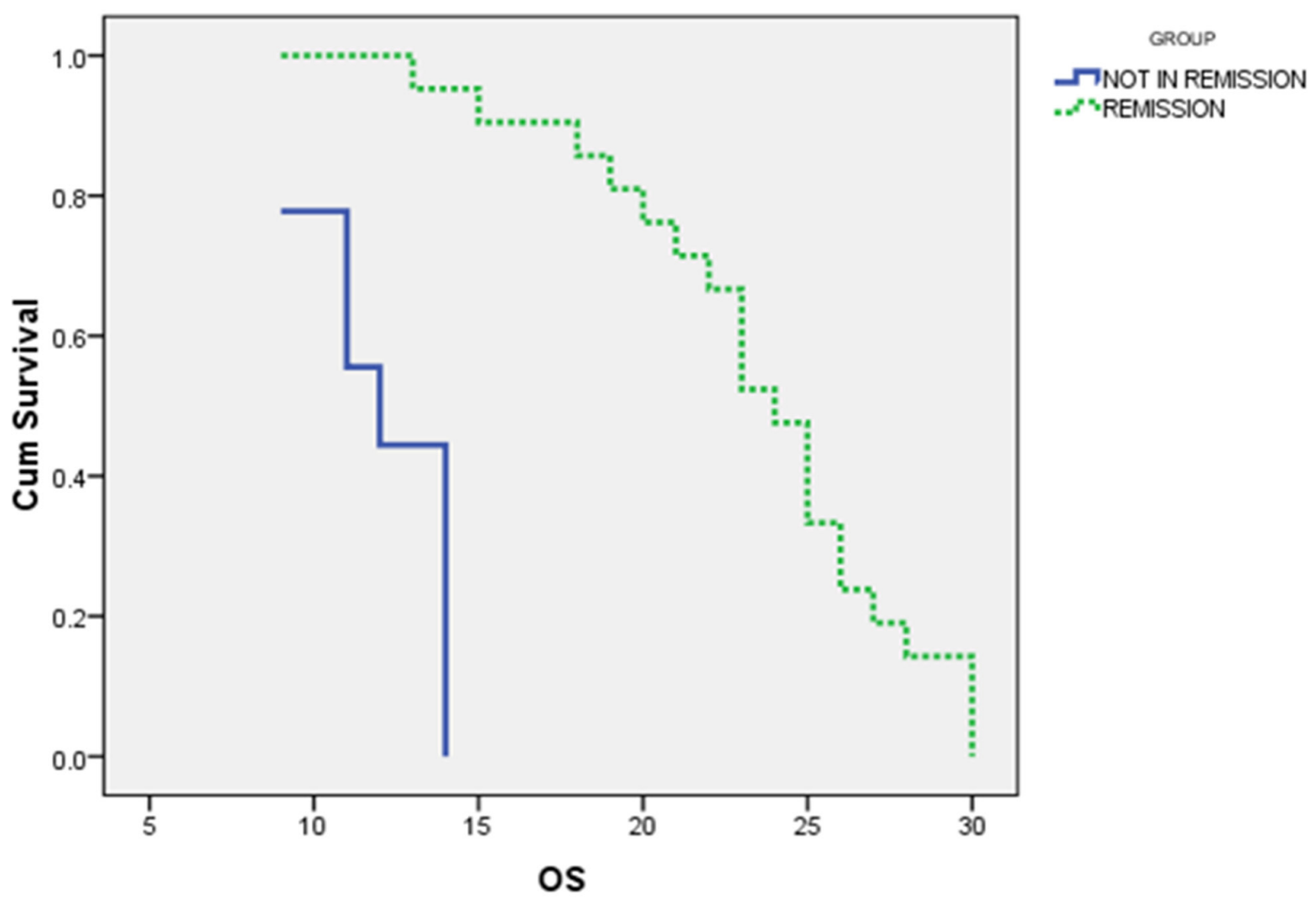

Figure 3: The Overall survival (OS) curves of AML patients with and without complete remission (CR): the median OS of AML patients with CR was 24 months, while for those with non CR was $12 \mathrm{~ms}(\mathbf{P}<0.000)$. 
cell counterparts. As CD123 is not found on normal HSCs, it may provide a unique marker for identification this malignant clone. This feature may be very useful in minimal residual disease studies as a single and standardized marker [28].

The percentage of the $\mathrm{CD} 34^{+} \mathrm{CD} 38^{\text {low/- }}$ population at diagnosis strongly correlates with clinical outcome, in addition, survival and outgrowth of leukemia cells after therapy may depend on many factors including LSC load [24]. This supported our results that detected a negative impact of the percentage of $\mathrm{CD} 34^{+} \mathrm{CD} 38^{\text {low/- }} \mathrm{LSC}$ subpopulation on remission status and survival.

$\mathrm{CD} 34^{+} \mathrm{CD} 38^{-} \mathrm{CD} 123^{+}$cells represent highly resistant population to chemotherapy and might be responsible

\section{Survival Functions}

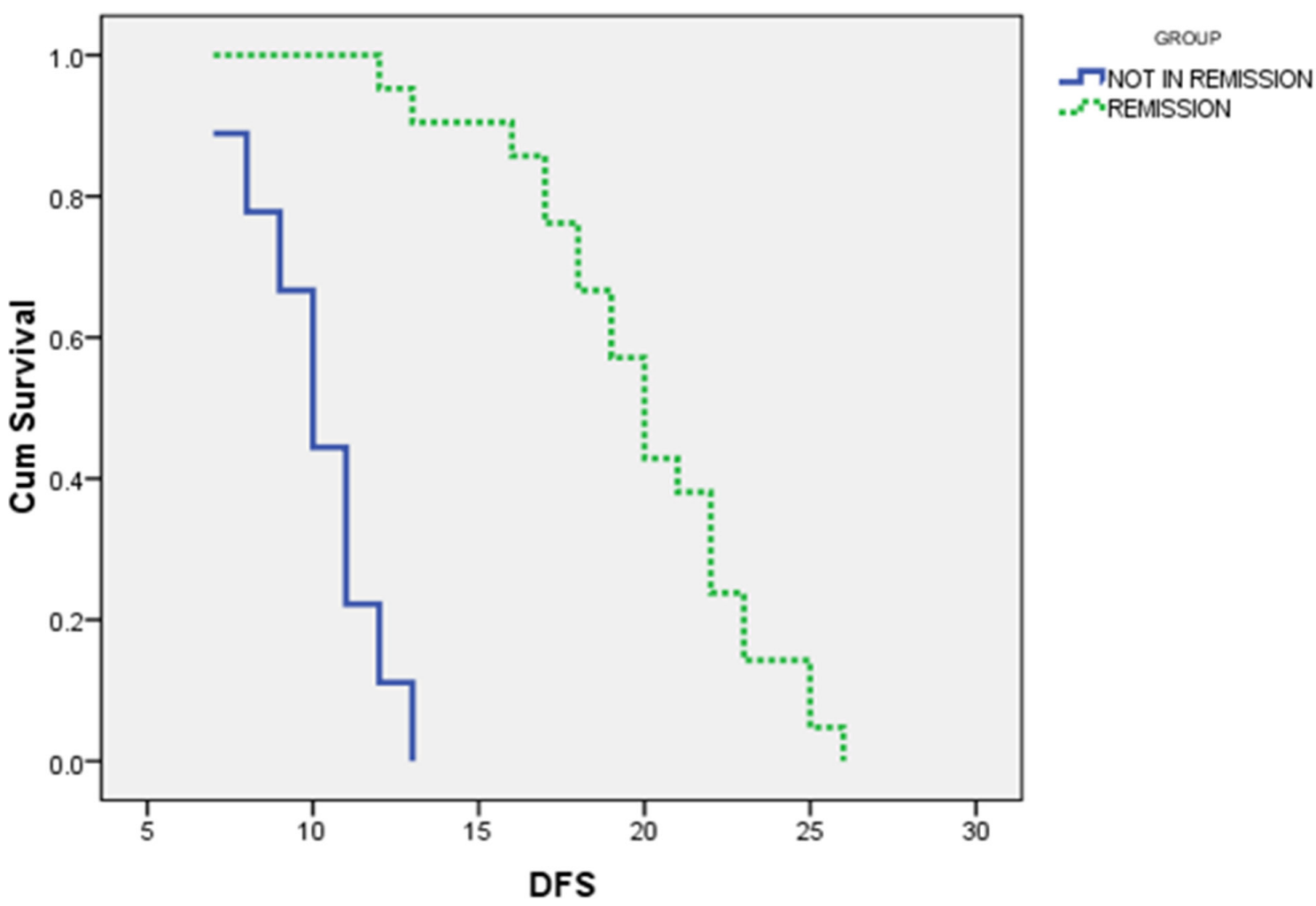

Figure 4: The Disease free survival curves of AML patients with and without complete remission (CR): the median DFS for AML patients with CR was 20 months, while for those with non CR was 10 months, $P<0.000$.
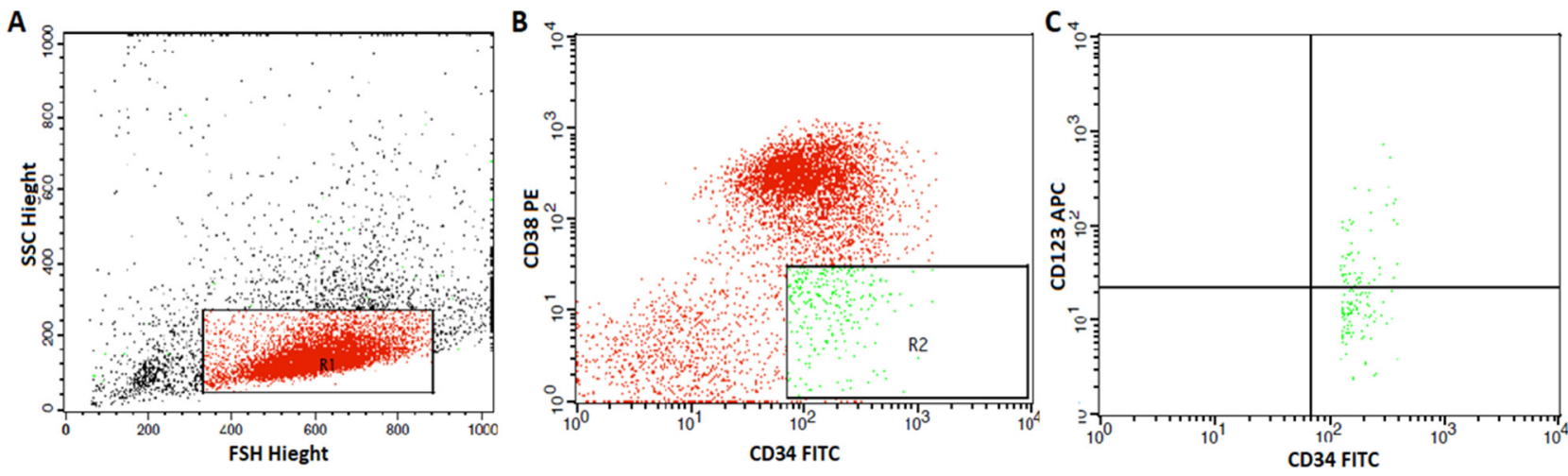

Figure 5: Flow cytometric detection of leukemic stem cells and their expression of CD123. (A) Forward and side scatter histogram was used to define the blast cells. (B) The expression of CD38 and CD34 were assessed on the blast cells and gate were drown to identify CD34+CD38-cells. (C) Then, the expression of CD123 were assessed on CD34+CD38-cells. 
for regrowth of leukemia and thus relapse of the disease as many studies proved that high level of CD $34^{+} \mathrm{CD} 38$ $\mathrm{CD}_{123}{ }^{+} \mathrm{LSCs}$ are predictive of poor EFS and OS [5, 29], collectively our results were in concordance with these studies.

Generally, eradication of blasts can be achieved by systemic multi-agent chemotherapy. However given that LSCs contained within $\mathrm{CD} 34^{+} \mathrm{CD} 38^{-} \mathrm{CD} 123^{+}$population in AML and difficulty to eradicate these malignant cells in this subgroup supports the hypothesis that in order to maintain complete remission after induction chemotherapy and to improve survival in AML patients, traditional chemotherapy targeting blasts should be combined with agents targeting LSCs.

With the poor prognosis of AML and only little improvements in treatment options, there is an imperative need for novel therapies, so therapies targeting LSC may offer a hope for prognostic improvement. In this regard, selection of the target highly expressed by LSCs and the timing of therapy may result in improved prognosis.

\section{PATIENTS AND METHODS}

In our study, we investigated 30 patients with newly diagnosed AML attending to South Egypt Cancer Institute, from May 2016 to October 2017. The study protocol followed the ethical guidelines of the 1975 Helsinki Declaration and was approved by the Ethical and Research committee of South Egypt Cancer Institute, Assiut University. An informed written consent in accordance was taken from all cases. Diagnosis of AML was achieved by morphologic, cytochemical, immunophenotypic and cytogenetic studies.

\section{All patients were subjected to:}

- Complete history taking, thorough physical and clinical examination.

- Complete blood count (CBC) including differential leukocyte count was done Using cell dyne 3500 automated cell counter (ABBOTT DIAGNOSTIC).

- Peripheral smear examination and bone marrow aspiration examination.

- Cytochemistry studies, such as myeloperoxidase, esterases, acid phosphatase and Periodic acid-Schiff.

- Immunophenotyping of leukemic cells was performed routinely in bone marrow using monoclonal antibodies that were used for diagnosing AML included: CD34. CD13, CD33, CD117, CD15 and intracellular myeloperoxidase, CD14, HLA-DR, CD41, CD61 and antiglycophorin A. All monoclonal antibodies were purchased from Becton Dickinson (BD) Bioscience, CA, USA.

- Flow cytometric detection of LSCs and their expression of CD123

- Induction chemotherapy after diagnosis given for those younger than 60 years was in the form of anthracycline days 1-3 (Daunorubicin $60-90 \mathrm{mg} / \mathrm{m}^{2}$ or
Idarubicin $12 \mathrm{mg} / \mathrm{m}^{2}$ ) and Cytarabine 100-200 mg/m² continuous IV days 1-7 \pm Cladribine $5 \mathrm{mg} / \mathrm{m}^{2}$ days $1-5$. While for patients 60 years or older; the previous regimen was given for those with good performance; unfavorable cytogenetics or molecular markers; antecedent hematologic disorder; or therapy-related AML. And lower intensity therapy was given for those not candidate for intensive therapy like Cytarabine $20 \mathrm{mg} / \mathrm{m}^{2}$ SC twice daily days $1-10$, and others.

\section{Flow cytometric detection of $\mathrm{CD}^{+} 4^{+} \mathrm{CD}^{-} 8^{-} \mathrm{LSCs}$ and $\mathrm{CD}_{123}{ }^{+}$LSCs}

Ethylenediaminetetra-acetic acid (EDTA)anticoagulanted fresh bone marrow (BM) aspirates under complete aseptic conditions from patients with AML were collected at the time of diagnosis to measure the LSCs using FACS caliber flow cytometer (Becton Dickinson, San Jose, CA, USA). Fifty $\mu \mathrm{L}$ from BM was stained with $5 \mu \mathrm{L}$ of phycoerythrin (PE) conjugated anti CD38, fluoroisothiocyanate (FITC) conjugated anti CD34 (Bioscience, USA) and allophycocyanin (APC) conjugated anti-CD123 (all from BD Bioscience, CA, USA) and incubated in dark for $15 \mathrm{~min}$ in dark at room temperature. After incubation, red blood cells (RBCs) lyses and washing with phosphate buffered saline were done. Acquisition and analysis were performed using cell Quest soft ware. Leukemic blasts were gated in on the basis of characteristic forward and side scatter features. Then the expressions of CD34 and CD38 markers were evaluated in the leukemic blasts to detect CD34+CD38leukemic cells. Then the expression of CD123 marker was evaluated on CD34+CD38- LSCs. CD34+CD38- LSCs and $\mathrm{CD}_{34}{ }^{+} \mathrm{CD} 38^{-} \mathrm{CD} 123^{+}$cells $\left(\mathrm{CD} 123^{+} \mathrm{LSCs}\right)$ were expressed as a percentage of total blast cells (Figure 5).

\section{Statistics}

Data were presented as mean $\pm \mathrm{SE}$, percentages. For the association between quantitative variables and categorical dependant variables (remission, no remission) unpaired $t$-test test and Mann Whitney test were used, furthermore, $\mathrm{Chi}^{2}$ test was used to assess the relations between 2 categorical variables (response and FAB subtype), Pearson correlation was used to study the magnitude of association between different prognostic factors and survival.

Regarding the analysis of OS, and DFS of our patients, for the whole study group survival curves were constructed by Kaplan-Meier method, for comparison of DFS, and OS between two unpaired groups (remission, no remission) log rank test was used and differences with $\mathrm{P}$-value $<0.05$ being considered significant with $95 \%$ confidence interval (95\% CI), P-value $<0.01-0.001$ was considered moderately significant, and $\mathrm{P}$-value $<0.001$ was considered highly significant. 
The definitions used for calculation of survival followed the revised recommendations of the international working group for therapeutic studies [30]. OS was defined as the time interval between date of diagnosis and date of death or last follow up visit, while DFS was defined as the time interval between date of diagnosis and date of relapse, induction failure, or death from any other cause.

Remission was defined as the absence of signs and symptoms of the disease associated with normal CBC, and less than 5\% blasts in BMA. Deviation from these criteria of remission was considered no remission. All data were analyzed using SPSS version 21.

\section{CONCLUSIONS}

Our study elucidated that the $\mathrm{CD} 34^{+} \mathrm{CD} 38^{\text {low/- }} \mathrm{CD} 123^{+}$ phenotype is present in a significant proportion of $\mathrm{AML}$ patients and it may be responsible for resistance to traditional treatments, and high percentage of MRD that is translated into significantly high number of non $\mathrm{CR}$, poor DFS, and OS.

\section{ACKNOWLEDGMENTS}

The authors acknowledged all participating patients, and supporting colleagues.

\section{CONFLICTS OF INTEREST}

The authors declared that they had no potential conflicts of interest.

\section{FUNDING}

The authors didn't receive any fund from their institutions or any other agency, and their work was completely funded by them.

\section{REFERENCES}

1. Appelbaum FR, Rowe JM, Radich J, Dick JE. Acute myeloid leukemia. Hematology (Am Soc Hematol Educ Program). 2001; 2001:62-86. https://doi.org/10.1182/asheducation-2001.1.62.

2. Löwenberg B, Downing JR, Burnett A. Acute myeloid leukemia. N Engl J Med. 1999; 341:105162. https://doi.org/10.1056/NEJM199909303411407.

3. Bonnet D, Dick JE. Human acute myeloid leukemia is organized as a hierarchy that originates from a primitive hematopoietic cell. Nat Med. 1997; 3:730-37. https://doi.org/10.1038/nm0797-730.

4. Costello R, Mallet F, Chambost H, Sainty D, Arnoulet C, Gastaut JA, Olive D. The immunophenotype of minimally differentiated acute myeloid leukemia (AML-M0): reduced immunogenicity and high frequency of $\mathrm{CD} 34+/$
CD38- leukemic progenitors. Leukemia. 1999; 13:1513-18. https://doi.org/10.1038/sj.leu.2401519.

5. van Rhenen A, Feller N, Kelder A, Westra AH, Rombouts E, Zweegman S, van der Pol MA, Waisfisz Q, Ossenkoppele GJ, Schuurhuis GJ. High stem cell frequency in acute myeloid leukemia at diagnosis predicts high minimal residual disease and poor survival. Clin Cancer Res. 2005; 11:6520-27. https://doi.org/10.1158/1078-0432.CCR-05-0468.

6. Konopleva M, Andreeff M. Targeting the leukemia microenvironment. Curr Drug Targets. 2007; 8:685-701. https://doi.org/10.2174/138945007780830827.

7. Lane SW, Scadden DT, Gilliland DG. The leukemic stem cell niche: current concepts and therapeutic opportunities. Blood. 2009; 114:1150-57. https://doi.org/10.1182/blood-2009-01-202606.

8. Buzzai M, Licht JD. New molecular concepts and targets in acute myeloid leukemia. Curr Opin Hematol. 2008; 15:8287. https://doi.org/10.1097/MOH.0b013e3282f3ded0.

9. Chan WI, Huntly BJ. Leukemia stem cells in acute myeloid leukemia. Semin Oncol. 2008; 35:326-35. https://doi.org/10.1053/j.seminoncol.2008.04.003.

10. Dick JE, Bhatia M, Gan O, Kapp U, Wang JC. Assay of human stem cells by repopulation of NOD/SCID mice. Stem Cells. 1997; 15:199-203. https://doi.org/10.1002/stem.5530150826.

11. Du X, Ho M, Pastan I. New immunotoxins targeting CD123, a stem cell antigen on acute myeloid leukemia cells. J Immunother. 2007; 30:607-13. https://doi.org/10.1097/CJI.0b013e318053ed8e.

12. Jordan CT. Unique molecular and cellular features of acute myelogenous leukemia stem cells. Leukemia. 2002; 16:559-62. https://doi.org/10.1038/sj.leu.2402446.

13. van Rhenen A, Moshaver B, Kelder A, Feller N, Nieuwint AW, Zweegman S, Ossenkoppele GJ, Schuurhuis GJ. Aberrant marker expression patterns on the CD34+CD38stem cell compartment in acute myeloid leukemia allows to distinguish the malignant from the normal stem cell compartment both at diagnosis and in remission. Leukemia. 2007; 21:1700-07. https://doi.org/10.1038/sj.leu.2404754.

14. Hosen N, Park CY, Tatsumi N, Oji Y, Sugiyama H, Gramatzki M, Krensky AM, Weissman IL. CD96 is a leukemic stem cell-specific marker in human acute myeloid leukemia. Proc Natl Acad Sci USA. 2007; 104:11008-13. https://doi.org/10.1073/pnas.0704271104.

15. Al-Mawali A. Leukemic stem cells shows the way for novel target of acute myeloid leukemia therapy. J Stem Cell Res Ther. 2013; 3:151. https://doi.org/10.4172/2157-7633.1000151.

16. Luo L, Han ZC. Leukemia stem cells. Int J Hematol. 2006; 84:123-27. https://doi.org/10.1532/IJH97.A10503.

17. Testa U. Leukemia stem cells. Ann Hematol. 2011; 90:24571. https://doi.org/10.1007/s00277-010-1118-7.

18. Costello RT, Mallet F, Gaugler B, Sainty D, Arnoulet C, Gastaut JA, Olive D. Human acute myeloid leukemia 
CD34+/CD38- progenitor cells have decreased sensitivity to chemotherapy and Fas-induced apoptosis, reduced immunogenicity, and impaired dendritic cell transformation capacities. Cancer Res. 2000; 60:4403-11.

19. Hwang K, Park CJ, Jang S, Chi HS, Kim DY, Lee JH, Lee JH, Lee KH, Im HJ, Seo JJ. Flow cytometric quantification and immunophenotyping of leukemic stem cells in acute myeloid leukemia. Ann Hematol. 2012; 91:1541-46. https://doi.org/10.1007/s00277-012-1501-7.

20. Wilson K, Case M, Minto L, Bailey S, Bown N, Jesson J, Lawson S, Vormoor J, Irving J. Flow minimal residual disease monitoring of candidate leukemic stem cells defined by the immunophenotype, CD34+CD38lowCD19+ in B-lineage childhood acute lymphoblastic leukemia. Haematologica. 2010; 95:67983. https://doi.org/10.3324/haematol.2009.011726.

21. le Viseur C, Hotfilder $\mathrm{M}$, Bomken S, Wilson $\mathrm{K}$, Röttgers S, Schrauder A, Rosemann A, Irving J, Stam RW, Shultz LD, Harbott J, Jürgens H, Schrappe M, et al. In childhood acute lymphoblastic leukemia, blasts at different stages of immunophenotypic maturation have stem cell properties. Cancer Cell. 2008; 14:4758. https://doi.org/10.1016/j.ccr.2008.05.015.

22. Jin L, Lee EM, Ramshaw HS, Busfield SJ, Peoppl AG, Wilkinson L, Guthridge MA, Thomas D, Barry EF, Boyd A, Gearing DP, Vairo G, Lopez AF, et al. Monoclonal antibody-mediated targeting of CD123, IL-3 receptor alpha chain, eliminates human acute myeloid leukemic stem cells. Cell Stem Cell. 2009; 5:31-42. https://doi.org/10.1016/j.stem.2009.04.018.

23. Eppert K, Takenaka K, Lechman ER, Waldron L, Nilsson B, van Galen P, Metzeler KH, Poeppl A, Ling V, Beyene J, Canty AJ, Danska JS, Bohlander SK, et al. Stem cell gene expression programs influence clinical outcome in human leukemia. Nat Med. 2011; 17:1086-93. https://doi.org/10.1038/nm.2415.

24. Terwijn M, Zeijlemaker W, Kelder A, Rutten AP, Snel AN, Scholten WJ, Pabst T, Verhoef G, Löwenberg B, Zweegman S, Ossenkoppele GJ, Schuurhuis GJ. Leukemic stem cell frequency: a strong biomarker for clinical outcome in acute myeloid leukemia. PLoS One. 2014; 9:e107587. https://doi.org/10.1371/journal.pone.0107587.
25. Plesa A, Elhamri M, Clapisson G, Mattei E, Gazzo S, Hequet O, Tigaud I, Michallet M, Dumontet C, Thomas $\mathrm{X}$. Higher percentage of CD34 + CD38- cells detected by multiparameter flow cytometry from leukapheresis products predicts unsustained complete remission in acute myeloid leukemia. Leuk Lymphoma. 2015; 56:62229. https://doi.org/10.3109/10428194.2014.927453.

26. Padilha SL, Souza EJ, Matos MC, Domino NR. Acute myeloid leukemia: survival analysis of patients at a university hospital of Paraná. Rev Bras Hematol Hemoter. 2015; 37:21-27. https://doi.org/10.1016/j.bjhh.2014.11.008.

27. van Buchem MA, te Velde J, Willemze R, Spaander PJ. Leucostasis, an underestimated cause of death in leukaemia. Blut. 1988; 56:39-44. https://doi.org/10.1007/BF00321058.

28. Al-Mawali A, Gillis D, Lewis I. The use of receiver operating characteristic analysis for detection of minimal residual disease using five-color multiparameter flow cytometry in acute myeloid leukemia identifies patients with high risk of relapse. Cytometry B Clin Cytom. 2009; 76:91-101. https://doi.org/10.1002/cyto.b.20444.

29. Vergez F, Green AS, Tamburini J, Sarry JE, Gaillard B, Cornillet-Lefebvre P, Pannetier M, Neyret A, Chapuis N, Ifrah N, Dreyfus F, Manenti S, Demur C, et al. High levels of CD34+CD381ow/-CD123+ blasts are predictive of an adverse outcome in acute myeloid leukemia: a Groupe Ouest-Est des Leucemies Aigues et Maladies du Sang (GOELAMS) study. Haematologica. 2011; 96:1792-98. https://doi.org/10.3324/haematol.2011.047894.

30. Cheson BD, Bennett JM, Kopecky KJ, Büchner T, Willman CL, Estey EH, Schiffer CA, Doehner H, Tallman MS, Lister TA, Lo-Coco F, Willemze R, Biondi A, et al, and International Working Group for Diagnosis, Standardization of Response Criteria, Treatment Outcomes, and Reporting Standards for Therapeutic Trials in Acute Myeloid Leukemia. Revised recommendations of the International Working Group for Diagnosis, Standardization of Response Criteria, Treatment Outcomes, and Reporting Standards for Therapeutic Trials in Acute Myeloid Leukemia. J Clin Oncol. 2003; 21:464249. https://doi.org/10.1200/JCO.2003.04.036. 